\title{
Carbon Isotope Discrimination, Gas Exchange, and Growth of Container-grown Conifers Under Cyclic Irrigation
}

\author{
Amanda J. Taylor ${ }^{1}$ and R. Thomas Fernandez ${ }^{2}$ \\ Department of Horticulture, Michigan State University, East Lansing, \\ MI 48824
}

Pascal Nzokou²
Department of Forestry, Michigan State University, East Lansing, MI 48824

Bert Cregg $^{2,3}$

Department of Horticulture and Department of Forestry, Michigan State University, 214 PSSB, East Lansing, MI 48824

Additional index words. water use efficiency, nursery production, Picea glauca, Picea pungens var. densata, Abies fraseri, Pinus strobus, needle conductance

\begin{abstract}
The objective of this study was to quantify the effects of cyclic irrigation on growth and physiology of container-grown conifer species in pot-in-pot (PIP) production in the upper Midwest. Trees of four conifer species (Picea glauca var. densata, Picea pungens, Abies fraseri, and Pinus strobus) were grown in 25- $\mathrm{L}$ containers and assigned to one of four combinations of irrigation rate (low or high) and daily irrigation cycle frequency (one or four). Irrigation rates were based on common nursery practice in the region $(2 \mathrm{~cm}$ rainfall equivalent/day) and one-half the standard rate $(1 \mathrm{~cm}$ rainfall equivalent/day). Cyclic irrigation increased relative height growth and relative caliper growth of Pinus strobus by over $80 \%$ and $35 \%$, respectively, compared with once-daily irrigation. The high-rate irrigation increased relative caliper growth of Picea pungens by $40 \%$ compared with the low rate. The effects of irrigation regime on needle- or shootlevel gas exchange varied by species and date of measurement. Carbon isotope discrimination $\left(\Delta^{13} \mathrm{C}\right)$ of needle and wood tissue was positively correlated $(r \geq 0.64, P<$ $0.001)$ with needle conductance to water vapor $\left(g_{w v}\right)$ and negatively correlated $(r \leq-\mathbf{0 . 6 0}$, $P<0.001)$ with intrinsic water use efficiency $\left(W U E_{i}\right)$. Carbon isotope discrimination of wood and needle tissue decreased with the low irrigation rate, indicating increased $W U E_{i}$ associated with reduced $g_{w v}$. Cyclic irrigation had relatively little effect on $\Delta^{13} \mathrm{C}$ except for Pinus strobus. Our findings suggest that carbon isotope composition of wood and needle tissue provides a sensitive and accurate representation of plant response to varying moisture availability. From a water management perspective, identifying optimal irrigation rates appears to be more important than number of daily cycles for these crops grown in the midwestern United States.
\end{abstract}

Nursery producers are in need of waterconserving irrigation methods that will allow them to adapt to increased water costs and stricter water withdrawal and discharge regulations (Beeson et al., 2004). Growers often

\footnotetext{
Received for publication 20 Dec. 2012. Accepted for publication 1 May 2013.

Funding for this study provided by Michigan State University Project GREEEN. In-kind contributions provided by Nursery Supplies, Inc., Scotts Co., Renewed Earth, Inc., and Peterson's Review Nursery.

We thank Dana Ellison, Brad Rowe, Erik Runkle, and three anonymous reviewers for their helpful reviews of a previous version of this manuscript. ${ }^{1}$ Former Graduate Research Assistant. Current address: North Carolina Cooperative Extension, 120 Hospital Drive, Suite 1, Lenoir, NC 28645.

${ }^{2}$ Associate Professor.

${ }^{3}$ To whom reprint requests should be addressed; e-mailcregg@msu.edu.
}

was $25 \%$ greater using cyclic irrigation compared with the traditional method of applying a single cycle in the morning (Beeson and Haydu, 1995; Fain et al., 1999; Witmer, 2000). These studies, however, were conducted in the southeastern United States or in greenhouses and may not reflect conditions common in nurseries in cooler climates such as the upper midwestern United States.

Improving our understanding of the physiological mechanisms behind the growth responses to irrigation is important in developing effective water management strategies. Up to $97 \%$ of water used by plants is transpired through stomata, and an initial response to limited water availability is stomatal closure (Halevy, 1972; Hand et al., 1982; Medrano et al., 2002; Taiz and Zeiger, 2006), which ultimately inhibits $\mathrm{CO}_{2}$ uptake and reduces photosynthetic assimilation $(A)$. It has been postulated that cyclic irrigation increases growth by removing or reducing midday water limitations, thereby increasing cumulative photosynthesis (Beeson, 1992; Witmer, 2000). For example, applying daily irrigation in two split applications consistently increased midday stomatal conductance $\left(g_{\mathrm{S}}\right)$ to water vapor for plants from three Rhododendron cultivars (Scagel et al., 2011). Cyclic irrigation, by maintaining higher substrate moisture content in the midday hours than one single application, delays or prevents stomatal closure, resulting in higher cumulative $A$ (Halevy, 1972; Warren and Bilderback, 2002).

Water use efficiency (WUE) is the relationship between assimilation and water loss and can be used to measure how efficiently a plant is using water to produce biomass (Anyia and Herzog, 2004). Several studies have demonstrated increases in WUE when trees are exposed to water-limiting irrigation regimes (Anyia and Herzog, 2004; Ningbo et al., 2009; Warren and Bilderback, 2002). Two methods are commonly used to estimate WUE for trees and shrubs: instantaneous WUE from measurements of leaf gas exchange and integrated WUE based on stable carbon isotope discrimination.

Instantaneous WUE measures WUE at the leaf level and is the ratio of the rate of $A$ to the rate of transpiration or the rate of leaf conductance to water vapor conductance. The ratio, $A / g_{w v}$, is often referred to as $W U E_{i}$, because it removes the effect of vapor pressure deficit inherent in WUE estimated from transpiration rate (Roussel et al., 2009). Intrinsic water use efficiency typically increases as plants undergo water stress, because $g_{w v}$ often decreases more rapidly than $A$ as water becomes limiting.

Estimating WUE from gas exchange can present logistical challenges in measurement and interpretation because gas exchange rates vary diurnally and seasonally. Because of this, stable carbon isotope $\left({ }^{13} \mathrm{C}\right)$ analyses have become an important method of assessing plant responses to environmental stress, especially water deficits (e.g., Farquhar et al., 1989). Plants discriminate against ${ }^{13} \mathrm{C}$ during photosynthesis, resulting in a lower ${ }^{13} \mathrm{C}$ isotopic composition in plant tissue than in the 
atmosphere. Empirical and theoretical studies have shown that the degree of discrimination against ${ }^{13} \mathrm{C}$ is determined largely by intercellular $\mathrm{CO}_{2}$ concentration, which is controlled by the ratio of $A$ to $g_{w v}$ (Farquhar et al., 1989). Stable carbon isotope discrimination may be used to estimate WUE during the time in which plant tissues, usually leaves or wood, are formed. Ecological studies have documented decreases in $\Delta^{13} \mathrm{C}$ of coniferous species in response to limited water availability (Aranda et al., 2010; Brandes et al., 2007; Olivas-Garcia et al., 2000; Zhang and Cregg, 2005). Because both $\Delta^{13} \mathrm{C}$ and $W U E_{i}$ are functions of $A$ and $g_{w v}$, they are often strongly correlated. However, $\Delta^{13} \mathrm{C}$ may provide some practical advantages in evaluating plant response to water availability because it integrates physiological responses over time rather than presenting a series of "snapshot" measurements.

Based on previous studies, we hypothesized that cyclic irrigation would reduce tree water stress and improve growth and plant WUE compared with conventional, once-aday irrigation. The objectives of this study were to 1) determine effects of cyclic irrigation programs on growth of container-grown conifers; and 2) explore underlying physiological mechanisms including various indicators of WUE.

\section{Materials and Methods}

Site description. This study was conducted at the Michigan State University Horticulture Teaching and Research Center (lat. $42.67^{\circ} \mathrm{N}$, long. $84.48^{\circ}$ E, elevation $264 \mathrm{~m}$ ) near East Lansing, MI. Trees were grown in 25-L (\#7) containers in a PIP production system. The soil on site was a well-drained loamy sand $(82.6 \%$ sand, $8.3 \%$ silt, $9.1 \%$ clay). Container spacing was $0.5 \mathrm{~m}$ and $1 \mathrm{~m}$ on-center within rows and between rows, respectively. Rims of the socket pots were $\approx 2.5 \mathrm{~cm}$ aboveground level and the ground was covered with landscape fabric to control weeds.

Plant materials. In Apr. 2008, 100 trees (25 of four species) were transplanted from 10-L (\#3) containers (GL1200; Nursery Supplies, Inc., Chambersburg, PA) into 25-L (\#7) containers (GL 2800) using an 80:20 (v:v) mix of pine bark and peatmoss (Renewed Earth, Inc., Kalamazoo, MI). Container capacity of the media was $44.5 \%$. The four species used were Fraser fir [Abies fraseri (Pursh) Poir.], Colorado blue spruce (Picea pungens Engelm. var. glauca Regel), black hills spruce [Picea glauca (Moench) Voss

Table 1. Mean ( \pm SE) height and caliper of container-grown trees of four species at the start of cyclic irrigation trial.

\begin{tabular}{lrc}
\hline Species & \multicolumn{1}{c}{$\mathrm{Ht}(\mathrm{cm})$} & Stem caliper $(\mathrm{mm})$ \\
\hline Picea glauca & $68.8(3.0)$ & $27.2(0.6)$ \\
Picea pungens & $68.4(2.6)$ & $28.3(0.8)$ \\
Abies fraseri & $69.8(2.4)$ & $26.0(0.7)$ \\
Pinus strobus & $111.3(2.8)$ & $33.9(1.1)$ \\
$\mathrm{N}=16$ & \\
\hline
\end{tabular}

var. densata], and eastern white pine (Pinus strobus L.) (Table 1). All plants were originally obtained from a local nursery (Petersons Riverview Farm, LLC, Allegan, MI) as seedling transplants in 2006 and then grown for 2 years in $10-\mathrm{L}$ containers in an $80 \%$ pine bark:20\% peatmoss (v:v) substrate.

Irrigation treatments. Daily irrigation volumes were based on daily water use estimates of similar species from Warsaw et al. (2009). Four trees of each species were randomly assigned to one of four irrigation regimes. Treatments consisted of a combination of daily irrigation rate (low or high) and daily irrigation cycle frequency (one or four). There were eight rows of trees in the study. Each row was assigned at random to receive once-daily irrigation $(1 \times)$ or cyclic irrigation applied four times daily (4X). Once-daily irrigation events occurred at $0600 \mathrm{HR}$. Cyclic irrigation treatments were applied at 0600 , 1000,1400 , and $1800 \mathrm{HR}$ daily to apply $25 \%$ of the daily total at each watering. Within each row, irrigation volume (high or low) was assigned at random. Low $(950 \mathrm{~mL})$ and high $(1900 \mathrm{~mL})$ irrigation rates of trees corresponded to $1 \mathrm{~cm}$ and $2 \mathrm{~cm}$ rainfall equivalent, respectively. Irrigation was applied from 15 May 2008 to 25 Sept. 2008 and from 21 May to 1 Oct. 2009. Irrigation was controlled by two timers (8014 Series Solo Rain; Nelson Irrigation Corp., Walla Walla, WA); one timer ran once daily, and the other ran four times per day. Irrigation rate was controlled by selection of an emitter using pressure-compensating spray stakes (Netafim, Fresno, CA).

Containers were top-dressed with $130 \mathrm{~g}$ of $15 \mathrm{~N}-4 \mathrm{P}-10 \mathrm{~K}$ controlled-release fertilizer (Osmocote ${ }^{\circledR}$ Plus 8-9 month release; The Scotts Co., Marysville, $\mathrm{OH}$ ) in the spring of 2008 and 2009. Weeds within containers were controlled through hand-weeding. Pots were turned periodically during the growing seasons to prevent rooting into the native soil.

The experimental treatments were arranged in a four $\times$ two $\times$ two factorial with four species $\times$ two irrigation rates $\times$ two irrigation cycle frequencies. There were four experimental units (trees) for each species $\times$ irrigation rate $\times$ cycle frequency combination. The plot of study trees was surrounded by a guard row of similarly sized trees.

Growth. Tree growth (caliper and height) was measured at the beginning and end of each growing season. Initial tree height was measured with a meter stick to the highest live point of the tree. Trunk caliper was assessed using a digital caliper. Two caliper measurements were taken perpendicular to each other, north-south-oriented and eastwest-oriented, at a height level even with the rim of the container. Relative growth rates were calculated as height (or caliper) growth during the study divided by the initial height (or caliper).

Gas exchange measurements-Picea spp. and Abies fraseri. Photosynthetic gas exchange was measured on three dates in the 2009 growing season using a portable gas exchange system (LI-6400; LI-COR Inc., Lincoln, NE) equipped with a $0.2-\mathrm{L}$ cylindrical conifer chamber (LI-6400-05). Lightsaturated photosynthesis $\left(A_{\max }\right)$ and $g_{w v}$ were assessed on all trees between $1100 \mathrm{HR}$ and $1500 \mathrm{HR}$ on 24 July, 6 Aug., and 31 Aug. One south-facing shoot of the current season's growth was selected from the upper third of each tree and flagged so that it could be used in subsequent gas exchange sampling. Gas exchange was measured on clear days [photosynthetic photon flux $(P P F)>1500$ $\mu \mathrm{mol} \cdot \mathrm{m}^{-2} \cdot \mathrm{s}^{-1}$ ] using a $\mathrm{CO}_{2}$ concentration at $400 \mu \mathrm{mol} \cdot \mathrm{mol}^{-1}$ and flow of air at 500 $\mathrm{mL} \cdot \mathrm{min}^{-1}$. To minimize temperature effects during each measurement run, the temperature controller of the photosynthesis system was set at the predicted high temperature for the day. Measurements were recorded after the readings had stabilized on the system's real-time graphics screen. At the end of each season (15 Oct. 2008 and 28 Oct. 2009), shoots used for gas exchange measurements were harvested and scanned using a leaf area meter (LI-3000; LI-COR Inc.) to obtain the projected shoot area, by which gas exchange measurements were adjusted. Intrinsic water

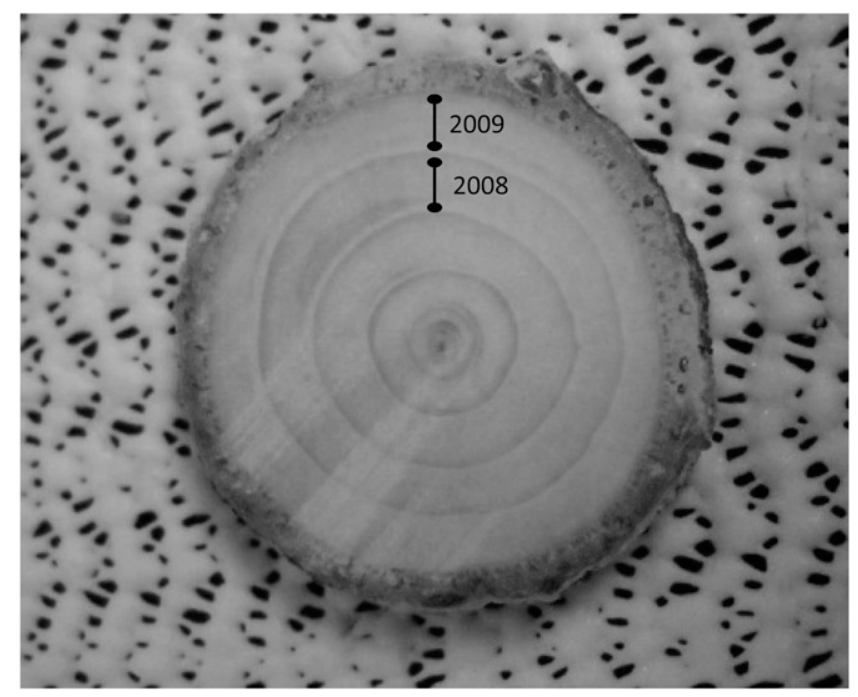

Fig. 1. Sample cross-section of conifer stem before sectioning into individual annual rings for ${ }^{13} \mathrm{C}$ analysis. 
Table 2. Mean $( \pm \mathrm{SE})$ height and stem caliper growth of four conifer tree species grown under four combinations of irrigation rate cycle frequency for 2 years.

\begin{tabular}{|c|c|c|c|c|c|c|c|}
\hline Cycles per day & \multicolumn{2}{|c|}{ Irrigation rate: Low } & \multicolumn{2}{|c|}{ Irrigation rate: High } & \multicolumn{3}{|c|}{ Effect $^{2}$} \\
\hline Picea glauca & $0.54(0.04)$ & $0.34(0.06)$ & $0.61(0.03)$ & $0.49(0.04)$ & $*$ & $* *$ & NS \\
\hline Picea pungens & $0.46(0.04)$ & $0.47(0.09)$ & $0.58(0.06)$ & $0.49(0.02)$ & NS & NS & NS \\
\hline \multirow[t]{2}{*}{ Pinus strobus } & $0.35(0.03)$ & $0.68(0.10)$ & $0.41(0.03)$ & $0.62(0.05)$ & NS & $* * *$ & NS \\
\hline & \multicolumn{4}{|c|}{ Relative caliper growth $\left(\mathrm{mm} \cdot \mathrm{mm}^{-1}\right)$} & & & \\
\hline Abies fraseri & $0.69(0.09)$ & $0.79(0.14)$ & $0.65(0.22)$ & $0.89(0.12)$ & NS & NS & NS \\
\hline Pinus strobus & $0.58(0.03)$ & $0.74(0.05)$ & $0.58(0.06)$ & $0.83(0.09)$ & NS & * & NS \\
\hline
\end{tabular}

${ }_{\mathrm{NSS}}, * * *, * * *$ Nonsignificant or significant at $P \leq 0.05,0.01$, or 0.001 , respectively.

$\mathrm{R} \times \mathrm{C}=$ rate $\times$ cycle.

Table 3. Summary repeated measures analysis of variance (F-values) for midday gas exchange of four conifer tree species grown under four combinations of irrigation rate (high or low) and cycle frequency $(1 \times$ or $4 \times$ daily).

\begin{tabular}{|c|c|c|c|c|}
\hline \multicolumn{5}{|c|}{$\begin{array}{l}\text { Species: Picea glauca, } P \text {. pungens, and Abies } \\
\text { fraseri }^{\mathrm{z}}\end{array}$} \\
\hline Source & & & F value $^{y}$ & \\
\hline $\begin{array}{l}\text { Between } \\
\text { subjects }\end{array}$ & $\mathrm{df}$ & $A_{\max }$ & $g_{w v}$ & $W U E_{i}$ \\
\hline Species (Spp) & 2 & $29.48^{* * *}$ & $32.28 * * *$ & $6.10^{* *}$ \\
\hline Cycles (C) & 1 & $7.51 * *$ & 1.82 & 0.02 \\
\hline $\mathrm{S} \times \mathrm{C}$ & 2 & $3.90 *$ & $4.70^{*}$ & 2.44 \\
\hline Rate (R) & 1 & $7.82 * *$ & $10.08^{* *}$ & 0.54 \\
\hline $\mathrm{S} \times \mathrm{R}$ & 2 & $3.54 *$ & $3.81^{*}$ & 1.04 \\
\hline $\mathrm{C} \times \mathrm{R}$ & 1 & 0.10 & 0.77 & 1.27 \\
\hline $\mathrm{S} \times \mathrm{C} \times \mathrm{R}$ & 2 & $6.57 * *$ & $8.82 * * *$ & 1.63 \\
\hline
\end{tabular}

Within subjects

$\begin{array}{lllll}\text { Day (D) } & 2 & 46.71^{* * *} & 55.55 * * * & 18.79^{* * *} \\ \mathrm{D} \times \mathrm{S} & 4 & 3.70^{* *} & 9.34^{* * *} & 3.29^{*} \\ \mathrm{D} \times \mathrm{C} & 2 & 19.63^{* * *} & 7.15^{* *} & 0.04 \\ \mathrm{D} \times \mathrm{R} & 2 & 0.30 & 0.32 & 0.45 \\ \mathrm{D} \times \mathrm{S} \times \mathrm{R} & 4 & 1.53 & 1.40 & 0.50 \\ \mathrm{D} \times \mathrm{S} \times \mathrm{C} & 4 & 3.08^{*} & 1.41 & 0.82 \\ \mathrm{D} \times \mathrm{C} \times \mathrm{R} & 2 & 0.35 & 0.31 & 0.63 \\ \mathrm{D} \times \mathrm{S} \times & 4 & 0.28 & 0.72 & 0.65 \\ \quad \mathrm{C} \times \mathrm{R} & & & & \end{array}$

\begin{tabular}{lcccl}
\multicolumn{5}{c}{ Species: Pinus strobus } \\
\hline Source & \multicolumn{5}{c}{ F value } \\
\hline $\begin{array}{c}\text { Between } \\
\quad \text { subjects }\end{array}$ & df & $A_{\max }$ & $g_{w v}$ & $W U E_{i}$ \\
$\quad$ Cycles (C) & 1 & 1.62 & 0.86 & $4.37^{*}$ \\
Rate (R) & 1 & 1.16 & $4.19^{*}$ & 1.46 \\
$\mathrm{C} \times \mathrm{R}$ & 1 & 3.05 & 2.21 & 0.02
\end{tabular}

Within subjects

$\begin{array}{llccc}\text { Day (D) } & 2 & 103.57 * * * & 89.60 * * * & 97.77 \\ \mathrm{D} \times \mathrm{C} & 2 & 0.87 & 0.01 & 3.08 \\ \mathrm{D} \times \mathrm{R} & 2 & 0.40 & 3.40^{*} & 4.27 * \\ \mathrm{D} \times \mathrm{C} \times \mathrm{R} & 2 & 0.93 & 1.15 & 0.01\end{array}$

${ }^{\mathrm{z}}$ Gas exchange of Picea spp. and Abies fraseri expressed on projected shoot area basis; gas exchange of Pinus strobus expressed on projected needle area basis; therefore, Pinus strobus was analyzed separately.

y*, ${ }^{* *},{ }^{* *}$ Significant at $P \leq 0.05,0.01$, or 0.001 , respectively.

$A_{\max }=$ light-saturated photosynthesis; $g_{w v}=$ stomatal conductance to water vapor; $W U E_{i}=$ intrinsic water use efficiency.

use efficiency was calculated as: $W U E_{i}=$ $A_{\max } / g_{w v}$.

Gas exchange measurements-Pinus strobus. Gas exchange of Pinus strobus was sampled
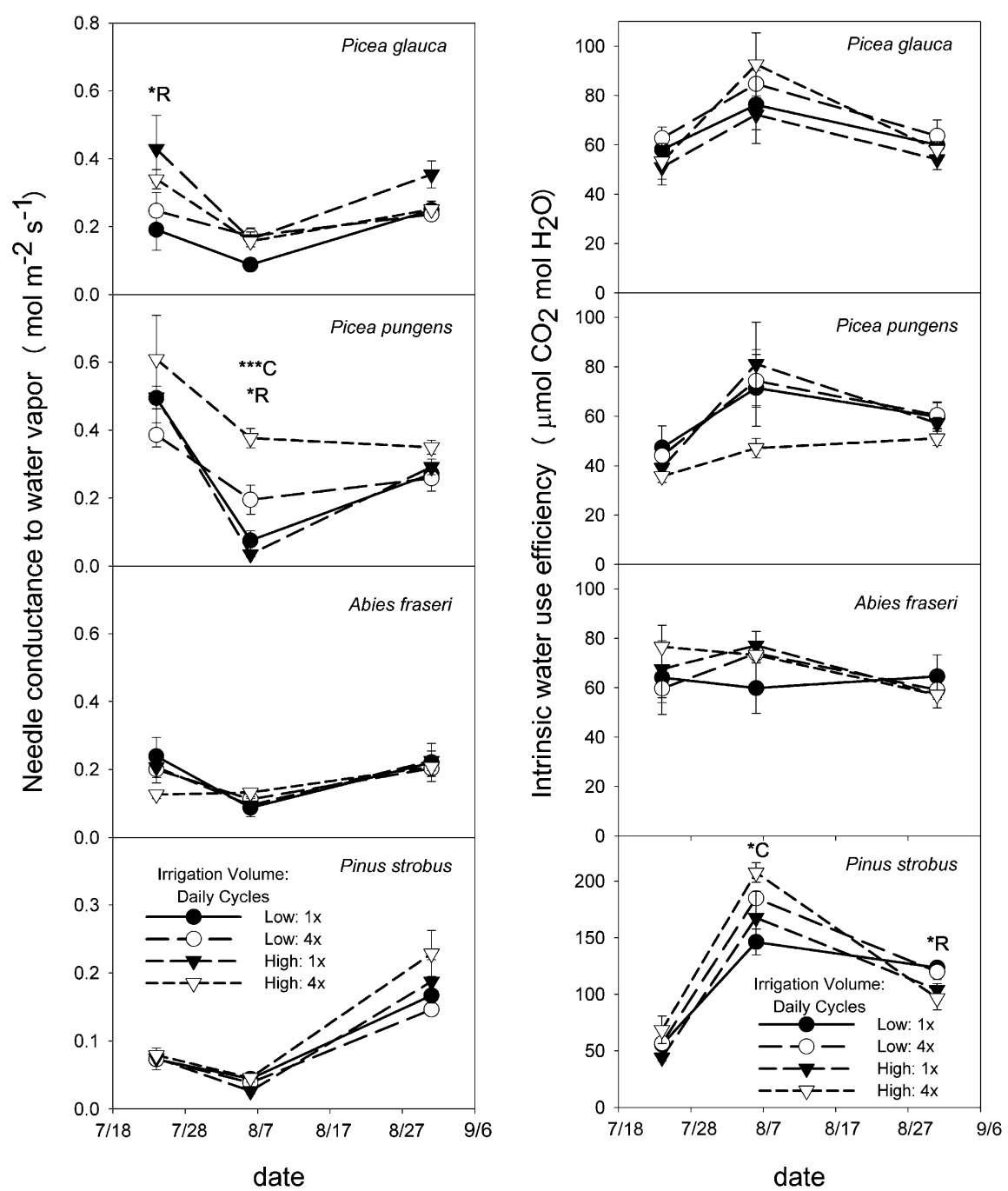

Fig. 2. Mean $( \pm \mathrm{SE})$ midday gas exchange of container-grown conifers from four species grown under four combinations of irrigation rate (high or low) and cycle frequency $(1 \times$ or $4 \times)$. Letters above means denote effect of irrigation rate $(\mathrm{R})$ or cycle frequency $(\mathrm{C})$ for a given date. $*, * *, * * *$ significant at $P \leq$ $0.05,0.01$, or 0.001 , respectively. $\mathrm{R} \times \mathrm{C}$ effect was not significant $(P>0.05)$ for either variable on any date.

as described previously; however, because the pine needles were too long to fit in the conifer chamber, a $3 \times 2$-cm leaf chamber equipped with a red + blue light-emitting diode light source (Li-6400-02B; LI-COR Inc.) was used to enclose a segment of needles. Two adjacent needle fascicles (10 needles) from the upper third of the tree were clamped inside the chamber. Care was taken to spread the needles inside the chamber to reduce mutual shading. Photosynthesis and $g_{w v}$ were measured using conditions within the chamber as described previously at a $P P F$ of $1500 \mu \mathrm{mol} \cdot \mathrm{m}^{-2} \cdot \mathrm{s}^{-1}$. Needle leaf area was estimated by assuming each needle represents one-fifth of a cylinder (Johnson, 1984). Needle fascicles were 
harvested after gas exchange measurements and the average radius ( $r$ ) of three needles was determined under a dissecting microscope with an eyepiece micrometer. Total surface area (TSA) was calculated based on 10 needles per sample and a chamber length of $3 \mathrm{~cm}$ as:

$$
\mathrm{TSA}=(2 \mathrm{r}+2 \pi \mathrm{r} / 5) \times 3 \times 10
$$

Foliar nutrient analysis. A subsample of current-year needles was harvested from each tree on 27 July 2009, dried, and sent to a commercial laboratory to be analyzed for nitrogen concentration using a $\mathrm{C} \& \mathrm{~N}$ analyzer (Scotts Inc., Lincoln, NE).

Carbon isotope discrimination. All trees were sampled for $\Delta^{13} \mathrm{C}$ in foliage and wood tissue. At the end of the 2009 season (28 Oct. 2009), randomly selected branches were harvested, separated by year (2008 and 2009 growth), and dried to a constant weight. Needles were removed and ground to pass through a 40-mesh screen. For Pinus strobus, only 2009 needles were sampled as a result of senescence of 2008 needles. At the time of foliar harvest, stem tissue was sampled using loppers or a saw. A 1-cm thick disc of the stem was removed at a height equal to the rim of the container (where stem caliper was measured), and 2008 and 2009 growth rings were identified (Fig. 1). Stem discs were sanded with 150-grit sandpaper to aid in distinguishing growth rings, and outer bark was removed. Growth rings were separated by year (2008 and 2009) using a hammer and chisel, and tissue was ground in a Wiley mill. Ground foliar tissue $(2-3 \mathrm{mg}$ ) and wood tissue $(1-2 \mathrm{mg}$ ) were passed through a 40-mesh sieve, packed into $5 \times 9$-mm tin capsules, and placed in a 96-well sample tray. Samples were sent to the Center for Stable Isotope Biogeochemistry at the University of California-Berkeley ( $<$ http://dawsonlab. synthasite.com $/>$ ) for analysis of the relative abundance of ${ }^{13} \mathrm{C}$ and ${ }^{12} \mathrm{C}$. The resulting $\Delta$ values were expressed relative to Pee Dee Belemnite (limestone) international standards (Craig, 1957).

Weather. Mean maximum daily air temperatures during the growing seasons (1 May to 1 Oct.) were $25.0^{\circ} \mathrm{C}$ and $23.8^{\circ} \mathrm{C}$ for 2008 and 2009, respectively. Total precipitation amounts during that time were $462 \mathrm{~mm}$ in 2008 and $425 \mathrm{~mm}$ in 2009 . Total seasonal (1 May to 1 Oct.) reference evapotranspiration exceeded rainfall by $308 \mathrm{~mm}$ and 244 $\mathrm{mm}$ in 2008 and 2009, respectively.

Statistical analysis. Data were analyzed using SAS Version 9.1 software (SAS Institute Inc., Cary, NC). All variables were tested for normality using PROC UNIVARIATE. PROC MIXED was used to conduct analysis of variance (ANOVA) for all variables. Mean separation was performed using Tukey's adjustment. Pearson correlation coefficients for $\Delta^{13} \mathrm{C}$ and gas exchange variables were determined using PROC CORR.

\section{Results}

Growth. Relative height and caliper growth of trees varied by species $(P<0.001$, analysis not shown). In addition, there was a significant species $\times$ cycle frequency interaction $(P<$ 0.001 ) for relative height and caliper growth; therefore, data were analyzed by species (Table 2). Cyclic irrigation increased relative height growth of Pinus strobus, whereas cyclic irrigation decreased height growth of Picea glauca. Cyclic irrigation increased relative caliper growth of Pinus strobus but did not affect relative caliper growth of the other species. The high rate of irrigation increased height growth of Picea glauca and caliper growth of Picea pungens relative to trees receiving the low rate of irrigation (Table 2 ).

Gas exchange. Gas exchange $\left(A_{\max }, g_{w v}\right.$, and $W U E_{i}$ ) varied by species and date of sampling (Table 3 ). As a result of various interactions of irrigation regime, species, and date, data were analyzed by date and species (Fig. 2). The high irrigation rate increased $g_{w v}$ of Picea glauca on 24 July and of Picea pungens on 6 Aug. Cyclic irrigation increased $g_{w v}$ of Picea pungens on 6 Aug. Cyclic irrigation increased $W U E_{i}$ of Pinus strobus on 6 Aug., whereas the high irrigation rate increased $W U E_{i}$ of Pinus strobus on 30 Aug. For all other dates, $g_{w v}$ and $W U E_{i}$ were similar among irrigation treatments within each species.

Carbon isotope discrimination. Carbon isotope discrimination was highly correlated with both $g_{w v}$ and $W U E_{i}$ (Fig. 3). Needle conductance to water vapor was positively correlated with $\Delta^{13} \mathrm{C}$ of both wood tissue $(r=0.73$,
$P<0.0001)$ and needle tissue $(r=0.64, P<$ $0.0001)$. Intrinsic water use efficiency was negatively correlated with $\Delta^{13} \mathrm{C}$ of wood tissue $(r=-0.60, P<0.0001)$ and needle tissue $(r=$ $-0.66, P<0.0001)$. Overall, $\Delta^{13} \mathrm{C}$ of needle tissue and $\Delta^{13} \mathrm{C}$ of wood tissue were highly correlated $(r=0.78, P<0.0001)$, and the mean of $\Delta^{13} \mathrm{C}$ of needle tissue was $\approx 2$ per mil higher than that of wood tissue.

The overall ANOVA indicated that $\Delta^{13} \mathrm{C}$ of wood and needle tissue was affected $(P<$ 0.05 ) by species, year, irrigation rate, and cycle frequency (analysis not shown). Overall, the low irrigation rate reduced $\Delta^{13} \mathrm{C}$ compared with the high rate, whereas cyclic irrigation increased $\Delta^{13} \mathrm{C}$ relative to trees irrigated only once per day. When analyzed by year and species (Figs. 4 and 5), irrigation rate generally had a greater effect on $\Delta^{13} \mathrm{C}$ than cycle frequency. The high irrigation rate increased $(P<0.05) \Delta^{13} \mathrm{C}$ of wood tissue in four of eight cases (Fig. 4) and increased $\Delta^{13} \mathrm{C}$ of needle tissue in two of seven cases (Fig. 5). Cyclic irrigation, in contrast, did not affect $\Delta^{13} \mathrm{C}$ of needle tissue for any species $\times$ year combination and increased $\Delta^{13} \mathrm{C}$ of wood of Pinus strobus in 2009 only.

Plant nitrogen status. The high rate of irrigation decreased foliar nitrogen $(\mathrm{N})$ of Picea pungens and Pinus strobus compared with trees at the low irrigation rate (Table 4). Mean foliar $\mathrm{N}$ concentration of the Picea
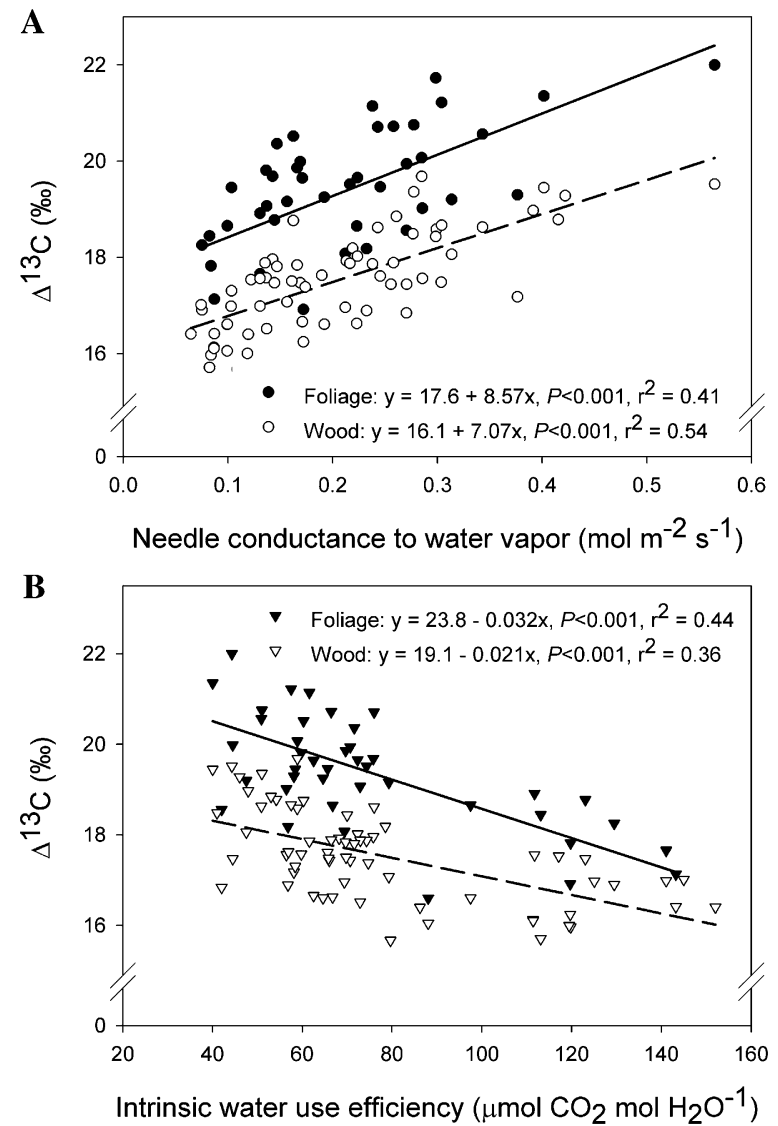

Fig. 3. Relationship between (A) carbon isotope discrimination $\left(\Delta^{13} C\right)$ of wood and needle tissue and conductance to water vapor and $(\mathbf{B})$ carbon isotope discrimination $\left(\Delta^{13} \mathrm{C}\right)$ of wood and needle tissue and intrinsic water use efficiency of container-grown conifers. 


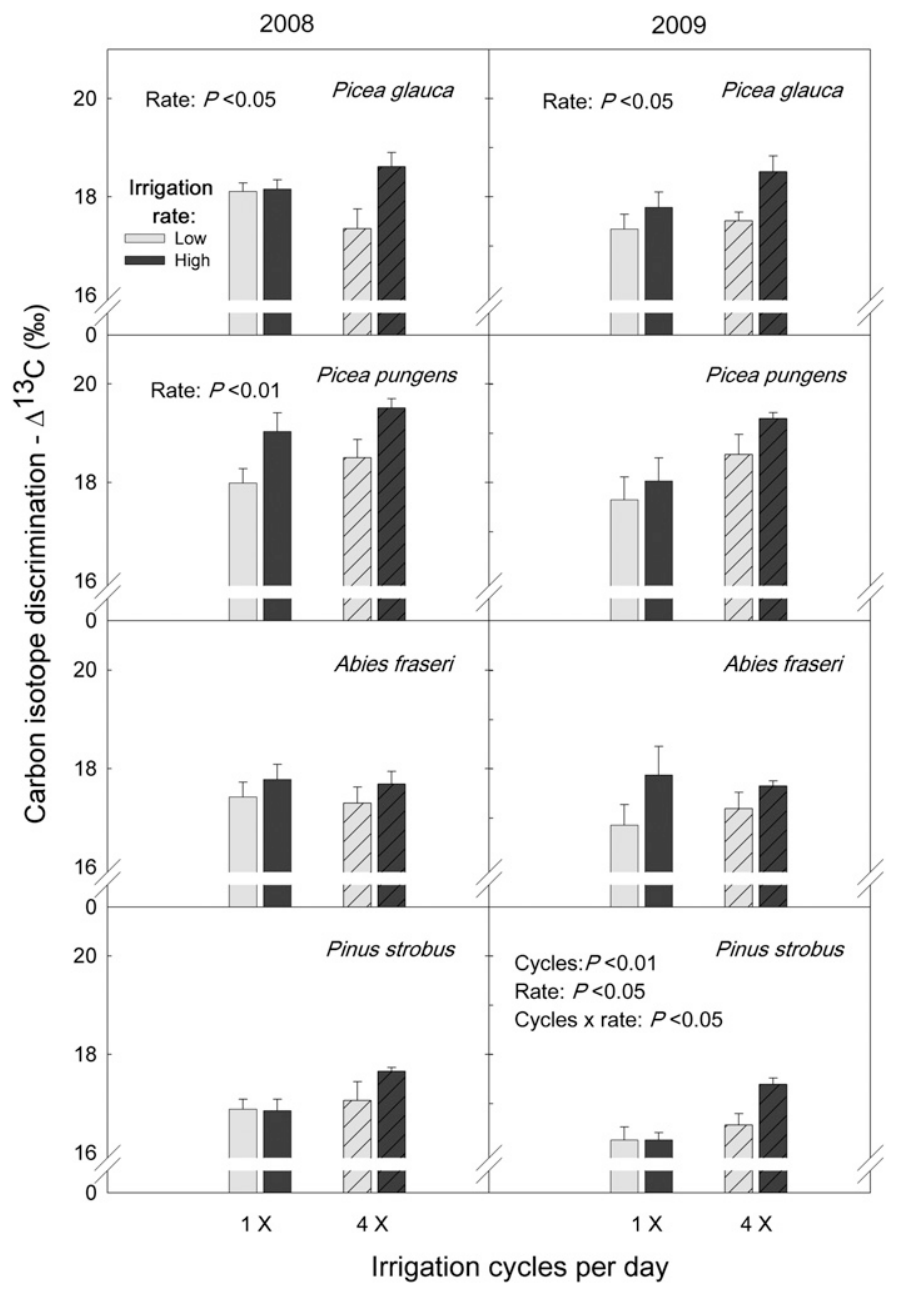

Fig. 4. Mean $( \pm \mathrm{SE})$ carbon isotope discrimination $\left(\Delta^{13} \mathrm{C}\right)$ of wood from 2008 (left panels) and 2009 (right panels) annual rings of four conifer tree species grown under four combinations of irrigation rate (high or low) and cycle frequency $(1 \times$ or $4 \times)$. Where significant, effect of irrigation rate, cycle frequency, and rate $\times$ cycle are indicated in each panel.

pungens was $3.5 \%$ with the low irrigation rate and $2.5 \%$ with the high irrigation rate. Mean foliar N of Pinus strobus was $2.3 \%$ and $1.8 \%$ under low and high irrigation rates, respectively. Irrigation rate did not affect foliar $\mathrm{N}$ of Abies fraseri or Picea glauca, and foliar $\mathrm{N}$ was unaffected by cyclic irrigation for all species.

\section{Discussion}

We hypothesized that cyclic irrigation would increase growth compared with oncedaily applications of the same total water volume and that less water could be used to achieve this growth. Cyclic irrigation increased relative height and caliper growth of Pinus strobus (Table 2). This growth increase associated with cyclic irrigation is consistent with previous nursery studies testing cyclic irrigation (Beeson, 1992; Beeson and Haydu, 1995; Fain et al., 1999; Haydu and Beeson, 1997; Ruter, 1998; Witmer, 2000). Counter to our hypothesis, however, cyclic irrigation did not increase relative height or caliper growth in three other species investigated. The inconsistencies between our results and previous studies may reflect the fact that many studies on cyclic irrigation have largely been conducted on deciduous trees and shrubs under generally warmer conditions in the southern United States. In 2009, Michigan experienced its sixth coolest summer on record since 1895 . More importantly, the period from June to Aug. 2009 was the fifth coolest ever recorded for this period (National Oceanic and Atmospheric Association, 2009).

Except for Picea glauca, irrigation rate had relatively little effect on relative height growth (Table 2). This is in agreement with numerous studies, which have demonstrated equal or superior growth rates of woody ornamental crops at reduced irrigation volumes (Groves et al., 1998; Haydu and Beeson, 1997; Martin et al., 1989; Roberts and Schnipke, 1987). For example, Warsaw et al. (2009) found that deficit irrigation (replacing $75 \%$ of daily water use on 1 or 2 consecutive days) reduced water use of woody ornamental shrubs in 10 - $\mathrm{L}$ containers by $6 \%$ to $75 \%$ without affecting plant growth.

Previous studies testing cyclic irrigation on broadleaf woody ornamentals have attributed the resulting increase in growth to cumulative reductions in midday water stress (Beeson, 1992) and subsequent maintenance of $g_{S}$ (greater $g_{w v}$ ), therefore increasing net photosynthesis (Warren and Bilderback, 2002). Based on this theory, we expected that applying a pulse of irrigation in the afternoon would dampen the midday fluctuations of gas exchange; however, gas exchange data generally indicated similar midday $g_{w v}$ values regardless of irrigation cycle frequency (Fig. 2). The lack of a consistent effect of cyclic irrigation may be related to several factors. First, weather patterns in Michigan are generally cooler than in southern U.S. states such as Alabama, Florida, Georgia, and North Carolina, where most similar studies have been conducted. Second, conifers often have lower rates of water use than similarly sized deciduous trees or shrubs. Empirical models predict that conifers are more drought-tolerant than broadleaf trees and shrubs as a result of their lower osmotic potential, sunken stomata, and lignified guard cell walls (Gao et al., 2002). This may explain the relative unresponsiveness of conifers in our study to cyclic water applications compared with broadleaf trees and shrubs in previous studies.

Carbon isotope discrimination responses to irrigation were generally more consistent than growth or gas exchange responses and suggest that daily irrigation rate is more important than the number of irrigation cycles per day. The increase in $\Delta^{13} \mathrm{C}$, which we observed in response to irrigation rate, indicates that the high irrigation rate improved the water status of some species (Fig. 4). Water stress may potentially decrease $\Delta^{13} \mathrm{C}$ by altering intercellular $\mathrm{CO}_{2}$ through changes in photosynthesis, $g_{\mathrm{S}}$, or both (Farquhar et al., 1989). In the present study, variation in $\Delta \Delta^{13} \mathrm{C}$ appears to be more tightly coupled with $g_{w v}$ than $A$. Leaf and wood $\Delta \Delta^{13} \mathrm{C}$ values of trees receiving the high irrigation rate were equal to or exceeded those of trees receiving the low irrigation rate (Figs. 4 and 5), whereas foliar $\mathrm{N}$ concentrations were similar to or reduced by the high irrigation rate. Foliar $\mathrm{N}$ can be used as a surrogate for carboxylation capacity (Adams and Kolb, 2004; Field and Mooney, 1986). These contrasting responses indicate that reduced carboxylation capacity resulting from reduced foliar $\mathrm{N}$ at high irrigation rates was not a factor affecting $\Delta^{13} \mathrm{C}$ of trees. Thus, we speculate that $g_{w v}$ must be limiting assimilation of ${ }^{13} \mathrm{C}$ into plant tissue.

Water use efficiency based on gas exchange measurements is highly variable because it is a function of the relationship between $A$ and $g_{w v}$ and is only a snapshot of plant functions at one time. Carbon isotope discrimination may provide a more accurate and sensitive depiction of plant stress, because the ${ }^{13} \mathrm{C}$ isotopic signature is integrated over the entire duration of tissue formation (Farquhar et al., 1989). In the case of needle tissue, conifers at this location produce most of their needle growth from May through July. Diameter growth, in contrast, may continue into October if weather is sufficiently warm. This longer period of integration of the 


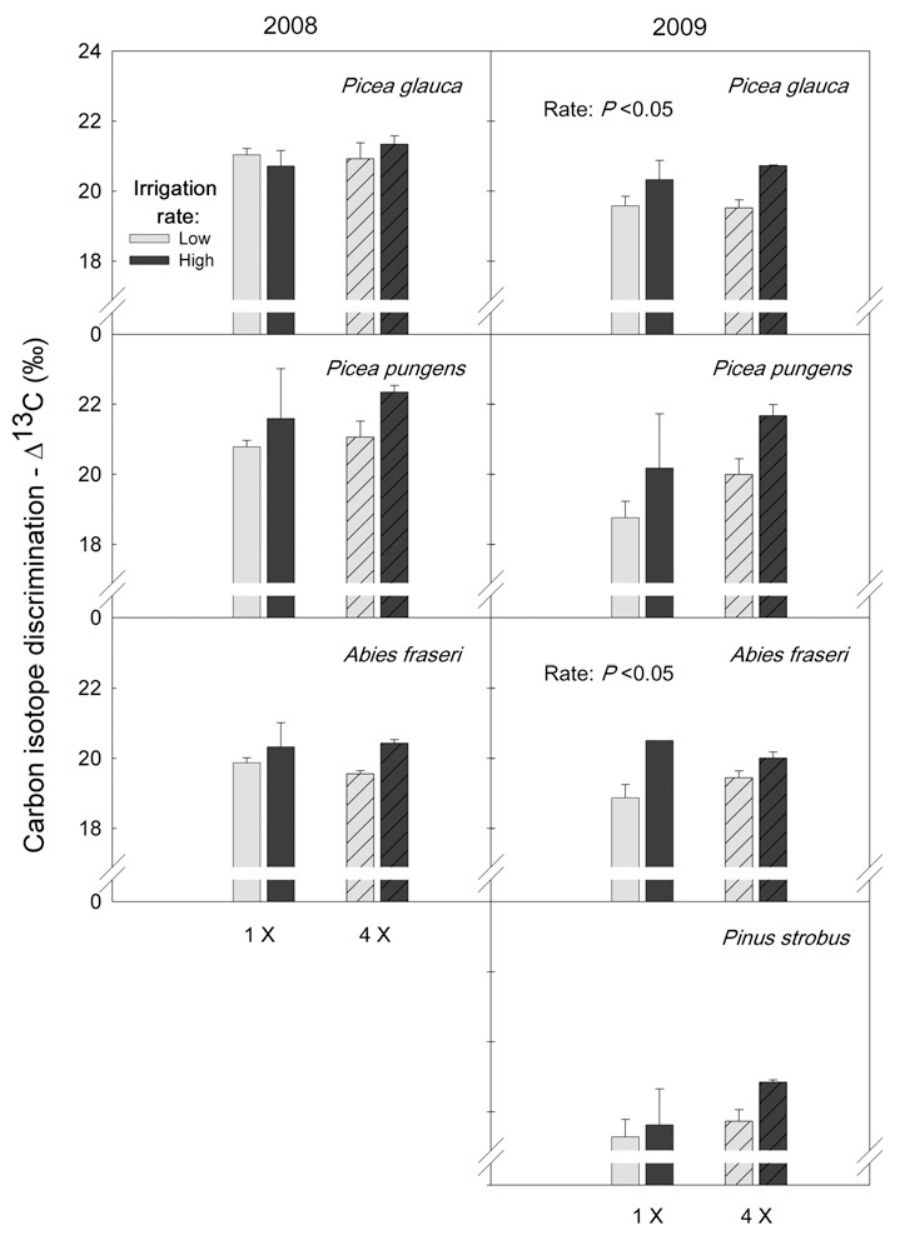

Irrigation cycles per day

Fig. 5. Mean $( \pm \mathrm{SE})$ carbon isotope discrimination $\left(\Delta^{13} \mathrm{C}\right)$ of needle tissue from 2008 (left panels) and 2009 (right panels) of four conifer tree species grown under four combinations of irrigation rate (high or low) and cycle frequency $(1 \times$ or $4 \times)$. Where significant, effect of irrigation rate, cycle frequency, and rate $\times$ cycle frequency are indicated in each panel. Note: 2008 needles on Pinus strobus had begun to senesce at the time of sampling.

Table 4. Mean end-of-season 2009 nitrogen concentration $(\% ; \pm \mathrm{SE})$ of foliar samples from four coniferous tree species grown under varying combinations of irrigation rate and daily cycle frequency, Michigan State University Horticulture Teaching and Research, East Lansing, MI.

\begin{tabular}{llr}
\hline & \multicolumn{2}{c}{ Irrigation rate } \\
\cline { 2 - 3 } Species & \multicolumn{1}{c}{ Low } & \multicolumn{1}{c}{ High } \\
\hline Picea glauca & $2.94(0.15)$ & $2.87(0.10)$ \\
Picea pungens & $3.53(0.24)$ & $2.49^{* z}(0.12)$ \\
Abies fraseri & $2.55(0.13)$ & $2.23(0.11)$ \\
Pinus strobus & $2.33(0.11)$ & $1.75^{*}(0.07)$ \\
\hline z*Means within a row are different at $P \leq 0.05$
\end{tabular}

${ }^{13} \mathrm{C}$ signal may explain why we were able to identify more irrigation effects from wood samples than tissue samples (Figs. 4 and 5). Nevertheless, $\Delta^{13} \mathrm{C}$ was highly correlated and differed by $\approx 2 \%$, which is consistent with similar samples of conifers (Zhang and Cregg, 2005).

A frequently cited benefit of cyclic irrigation is increased nutrient efficiency and subsequent reduction in $\mathrm{N}$ lost resulting from leaching (Fare et al., 1994; Tyler et al., 1996). In the present study, we found nutrient retention to be a function of irrigation rate, not cycle frequency. Reduced foliar N levels of Picea pungens and Pinus strobus at the conventional (high) application rate indicate that growers may be leaching nutrients and sacrificing nutrient efficiency by using traditional irrigation methods (Table 4).

\section{Conclusion}

Among the four species examined, cyclic irrigation increased growth only of containergrown Pinus strobus compared with once-daily irrigation. It is possible that the beneficial effects of cyclic irrigation on growth were underestimated as a result of the mild summer of 2009 . Reducing irrigation rates by $50 \%$ from the standard rate reduced height growth of Picea glauca and caliper growth of Picea pungens but did not affect other growth measures, suggesting significant water savings are possible through reducing irrigation rates in container nurseries in the upper Midwest. Reduced foliar $\mathrm{N}$ levels at the traditional (high) application rate indicate that growers may be leaching nutrients and sacrificing nutrient efficiency using standard irrigation methods.
Reduced irrigate rate affected $\Delta^{13} \mathrm{C}$, especially wood tissue, suggesting that seasonlong isotope signal may indicate water stress effects that were too subtle to be indicated by growth responses. Our findings confirm that carbon isotope composition of wood and foliage tissue is a sensitive and accurate representation of plant response to varying moisture availability with logistical and theoretical advantages over gas exchange sampling.

\section{Literature Cited}

Adams, H.D. and T.E. Kolb. 2004. Drought responses of conifers in ecotone forests of northern Arizona: Tree ring growth and leaf 13C. Oecologia 140:217-225.

Anyia and Herzog. 2004. Water use efficiency, leaf area, and leaf gas exchange of cowpeas under mid-season drought. Eur. J. Agron. 20:327-339.

Aranda, I., R. Alia, U. Ortega, A.K. Dantas, and J. Majada. 2010. Intra-specific variability in biomass partitioning and carbon isotopic discrimination under moderate drought stress in seedlings from four Pinus pinaster seedlings. Tree Genet. Genomes 6:169-178.

Beeson, R.C., Jr. 1992. Restricting overhead irrigation to dawn limits growth in containergrown woody ornamentals. HortScience 27: 996-999.

Beeson, R.C., Jr., M.A. Arnold, T.E. Bilderback, B Bolusky, S. Chandler, H.M. Gramling, J.D Lea-Cox, J.R. Harris, P.J. Klinger, H.M. Mathers, J.M. Ruter, and T.H. Yeager. 2004. Strategic vision of container nursery irrigation in the next ten years. J. Env. Hort. 22:113-115.

Beeson, R.C., Jr., and J. Haydu. 1995. Cyclic microirrigation in container-grown landscape plants improves plant growth and water conservation. J. Env. Hort. 13:6-11.

Brandes, E., J. Wenninger, P. Koeniger, D. Schindler, H. Rennenberg, C. Leibundgut, H. Mayer, and A. Gessler. 2007. Assessing environmental and physiological controls over water relations in a Scots pine (Pinus sylvestris L.) stand through analyses of stable isotopic composition of organic matter. Plant Cell Environ. 30:113-127.

Craig, H. 1957. Isotopic standards for carbon and oxygen and correction factors for massspectrometric analysis of carbon dioxide. Geochim. Cosmochim. Acta 12:133-149.

Fain, G.B., K.M. Tilt, C.H. Gilliam, H.G. Ponder, and J.L. Sibley. 1999. Cyclic irrigation improves irrigation application efficiency and growth of sawtooth oak. J. Arboric. 25:200-203.

Fare, D.C., C.H. Gilliam, and G.J. Keever. 1994 Cyclic irrigation reduces container leachate nitrate nitrogen concentration. HortScience 29: 1514-1517.

Farquhar, G.D., J.R. Ehleringer, and K.T. Hubick. 1989. Carbon isotope discrimination during photosynthesis. Ann. Rev. Plant Physiol. Mol. Bio. 140:503-537.

Field, C. and H.A. Mooney. 1986. The photosynthesisnitrogen relationship in wild plants, p. 25-55. In: Givnish, T.J. (ed.). On the economy of plant form and function. Cambridge University Press, London, UK.

Gao, Q., P. Zhao, X. Zeng, X. Cai, and W. Shen. 2002. A model of stomatal conductance to quantify the relationship between leaf transpiration, microclimate and soil water stress. Plant Cell Environ. 25:1373-1381.

Groves, K.M., S.L. Warren, and T.E. Bilderback. 1998. Irrigation volume, application, and controlled-release fertilizers: I. Effect on plant growth and mineral nutrient content in 
containerized plant production. J. Environ. Hort. 16:176-181.

Halevy, A.H. 1972. Water stress and the timing of irrigation. HortScience 7:113-114.

Hand, M.J., E. Young, and A.C. Vanconcelos. 1982. Leaf water potential, stomatal resistance, and photosynthetic response to water stress in peach seedlings. Plant Physiol. 69:10511054.

Haydu, J.J. and R.C. Beeson, Jr. 1997. Economic feasibility of micro-irrigating container-grown landscape plants. J. of Environ. Hort. 15:23-29.

Ismail, S.M., K. Ozawa, and N.A. Khondaker. 2007. Influence of single and multiple water application timings on yield and water use efficiency in tomato (var. First Power). Agr. Water Mgt. 95:116-122.

Johnson, J.D. 1984. A rapid technique for estimating the total surface area of pine needles. For. Sci. 30:913-921.

Keever, G.J. and G.S. Cobb. 1985. Irrigation scheduling effects on container media and canopy temperatures and growth of 'Hershey Red' azalea. HortScience 20:921-923.

Martin, C.A., H.G. Ponder, and C.H. Gilliam. 1989. Effects of irrigation rate and media on growth of Acer rubrum L. in containers. J. of Env. Hort. 7:38-40.

Medrano, H., J.M. Escalona, J. Bota, J. Gulias, and J. Flexas. 2002. Regulation of photosynthesis of C-3 plants in response to progressive drought: Stomatal conductance as a reference parameter. Ann. Bot. (Lond.) 89:895-905.

National Oceanic and Atmospheric Association (NOAA). 2009. NOAA: Summer temperature below average for U.S. 10 Sept. 2009. <http:// www.noaanews.noaa.gov/stories2009/20090910_ summerstats.html $>$.

Ningbo, C., T. Dub, S. Kang, F. Li, X. Hua, M. Wang, and Z. Li. 2009. Relationship between stable carbon isotope discrimination and water use efficiency under regulated deficit irrigation of pear-jujube tree. Agr. Water Mgt. 96:16151622.

Olivas-Garcia, J.M., B.M. Cregg, and T.C. Hennessey. 2000. Genotypic variation in carbon isotope discrimination and gas exchange of ponderosa pine seedlings under two levels of water stress. Can. J. For. Res. 30:15811590.

Roberts, B.R. and V.M. Schnipke. 1987. The water requirements of five container-grown Acer species. HortScience 22:1161.

Roussel, M., E. Dreyer, P. Montpied, G. Le-Provost, J.M. Guehl, and O. Brendel. 2009. The diversity of ${ }^{13} \mathrm{C}$ isotope discrimination in a Quercus robur full-sib family is associated with differences in intrinsic water use efficiency, transpiration efficiency, and stomatal conductance. J. Expt. Bot. 60:2419-2431.

Ruter, J.M. 1998. Pot-In-Pot production and cyclic irrigation influence growth and irrigation efficiency of 'Okame' cherries. J. Environ. Hort. 16:159-162.

Scagel, C.F., G. Bi, L.H. Fuchigami, and R.P. Regan. 2011. Effects of irrigation frequency and nitrogen fertilizer rate on water stress, nitrogen uptake, and plant growth of containergrown Rhododendron. HortScience 46:15981603.

Taiz, L. and E. Zeiger. 2006. Plant physiology. 4th Ed. Sinauer Associates Inc., Sunderland, MA

Tyler, H.H., S.L. Warren, and T.E. Bilderback. 1996. Reduced leaching fractions improve irrigation use efficiency and nutrient efficacy. J. of Environ. Hort. 14:199-204.

Warren, S.L. and T.E. Bilderback. 2002. Timing of low pressure irrigation affects plant growth and water utilization efficiency. J. Environ. Hort. 20:184-188.

Warsaw, A.L., R.T. Fernandez, B.M. Cregg, and J.A. Andresen. 2009. Water conservation, growth, and water use efficiency of containergrown woody ornamentals irrigated based on daily water use. HortScience 44:1308-1318.

Witmer, R. 2000. Water use of landscape trees during pot-in-pot production and during establishment in the landscape. PhD diss., Virginia Polytechnic Institute and State University, VA.

Zhang, J. and B.M. Cregg. 2005. Growth and physiological responses to varied environments among populations of Pinus ponderosa. For. Ecol. Mgt. 219:1-12. 